\title{
Host specialisation and the disparate fate of Ceropales bipunctata (Hymenoptera: Pompilidae) in New Brunswick and Ontario, Canada
}

\author{
John Klymko, ${ }^{1}$ Matthias Buck, Sarah L. Robinson
}

\begin{abstract}
Ceropales bipunctata Say (Hymenoptera: Pompilidae) is a cleptoparasitic spider wasp that has declined significantly in parts of its range. New survey work has revealed that the species is common and widespread in dune habitat along the Gulf of Saint Lawrence in New Brunswick, Canada. Its host was determined as Anoplius cleora (Banks) (Hymenoptera: Pompilidae), with Arctosa littoralis (Hentz) (Araneae: Lycosidae) as prey, the first host record for this species. The relative abundance of $C$. bipunctata in coastal New Brunswick sharply contrasts with a decline in Ontario, Canada, where it was thought to be extirpated. Based on body size, habitat, and locality overlap we postulate that the primary host of $C$. bipunctata in Ontario and western Québec, Canada, is a different species, Anoplius aethiops (Cresson), with A. atrox (Dahlbom) as a likely secondary host in southwestern Ontario. Both species are closely related to A. cleora and have undergone a decline in eastern Canada. Based on these new findings, we reassess the conservation status of C. bipunctata in Canada.
\end{abstract}

\section{Introduction}

Ceropales bipunctata Say (Hymenoptera: Pompilidae), a species of spider wasp found in the eastern United States of America and southeastern Canada, is considered to potentially be of conservation concern due to a recent decline in collected specimens. In Canada, it has been recorded from Ontario, Québec, New Brunswick, and Prince Edward Island (Townes 1957; Godsoe 2004). In southern Ontario, this relatively showy species (Fig. 1) was commonly collected from the 1880s to the 1950s (Godsoe 2004, see also Fig. 8; Table 2). No specimens were collected between 1957 and 2004, and the species was thought to be extirpated from Ontario (Godsoe 2004). After 2004, it was rediscovered at three previously unknown localities in Ontario (see Results). However, a substantial decline is evident. We are confident that this trend reflects a real decline, not a lack of collecting effort. From 1999 to 2008, M.B. and co-workers at University of Guelph (Guelph, Ontario, Canada) conducted extensive surveys for aculeate Hymenoptera in various habitats in southern Ontario, which failed to detect the species. Data for other Canadian provinces are too scanty to determine an obvious trend, yet no recent material of $C$. bipunctata was found in any of the collections we contacted. Similarly, Godsoe (2004) was unable to find specimens from the United States of America collected after the early 1960s, suggesting a decline across the entire range. Due to this precarious situation, the species was identified as a high-priority candidate for assessment by the Committee on the Status of Endangered Wildlife in Canada (COSEWIC) in 2014.

Causes for the apparent decline of $C$. bipunctata were previously unclear. Like its congeners, C. bipunctata is a cleptoparasite, laying its eggs in the book lung of the paralysed spider prey that another spider wasp has captured (Townes 1957). Eggs are laid either while prey is being transported by the host wasp or while prey is lying unguarded (Krombein 1979). After emergence inside the host burrow, the larva of the parasite first consumes the host egg and then the spider (Townes 1957).

Received 16 January 2017. Accepted 11 May 2017. First published online 7 September 2017.

J. Klymko, ${ }^{1}$ S.L. Robinson, Atlantic Canada Conservation Data Centre, PO Box 6416, Sackville, New Brunswick, E4L 4G7, Canada

M. Buck, Invertebrate Zoology, Royal Alberta Museum, 9810-103a Avenue NW, Edmonton, Alberta, T5J 0G2, Canada

${ }^{1}$ Corresponding author (e-mail: john.klymko@accdc.ca)

Subject editor: Christopher Buddle

doi:10.4039/tce. 2017.40 
Fig. 1. Ceropales bipunctata male (Cap Lumière, New Brunswick, 20 August 2015).

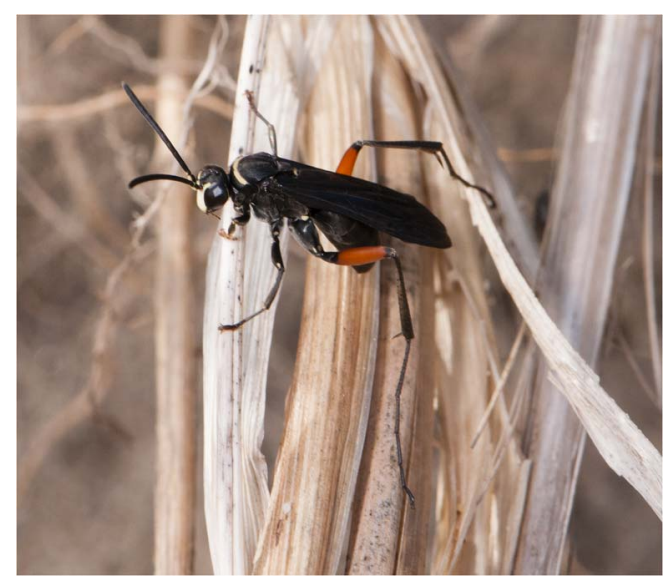

Godsoe (2004) speculated on host decline as a potential cause for the decline of $C$. bipunctata. The large size of this species rules out most spider wasps as potential hosts, leaving the larger species of Anoplius Dufour (Hymenoptera: Pompilidae) as potential candidates (Godsoe 2004). However, no host observations were available before our study.

The initial purpose of our study was to determine the conservation status of $C$. bipunctata in New Brunswick through targeted field surveys. The inspiration for our project came from recent observations of the species at two widely separated coastal dunes (Tingley 2012, 2013), demonstrating that this COSEWIC candidate remained extant in the province. The few historic and recent data on the distribution of this species in the Maritimes are summarised in the Results.

During our survey we were able to observe the host - indeed a species of Anoplius as had previously been speculated (Godsoe 2004). The host was detected at most of the sites where we found C. bipunctata. However, when we compared Ontario records of parasite and the newfound host we noticed that they were largely incongruent. We therefore set out to determine the putative host species for Ontario and adjacent areas of Québec through a process of elimination, comparing collection data and considering relevant biological parameters. The newly gained insights allowed us to test the hypothesis whether the decline of $C$. bipunctata in Ontario is indeed host-mediated.

\section{Methods}

\section{Survey work in New Brunswick}

To determine the current distribution of C. bipunctata in New Brunswick, we surveyed 33 coastal sand dune and beach sites along the Gulf of Saint Lawrence and Chaleur Bay (see Table 1 and Fig. 2). Dune habitats were targeted because the few recent New Brunswick records were from dunes (Tingley 2012, 2013). Historic records from Shippagan and Tracadie (see Results) lack habitat information, but both centres are close to extensive dunes. We only became aware of the historic record from Saint John (where coastal dunes are absent) after survey sites had been selected.

Surveys were conducted between 18 August and 3 September of 2015, which falls within the flight period of $C$. bipunctata in the Maritimes and Ontario. Surveys were conducted by one or two observers walking sites between 09:00 AM and 06:00 PM Atlantic Daylight Time on days of good weather (air temperature $\geqslant 15^{\circ} \mathrm{C}$, no precipitation, wind $<30 \mathrm{~km} /$ hour). We collected spider wasps opportunistically (including specimens of other genera), with the goal to voucher a specimen of $C$. bipunctata at every site where it was encountered. We took notes about $C$. bipunctata behaviour and captured any spider wasps plus their spider prey that were parasitised by C. bipunctata. All specimens are deposited at the New Brunswick Museum (Saint John, New Brunswick, Canada) and the Royal Alberta Museum (Edmonton, Alberta, Canada).

\section{Inference of the putative Ceropales bipunctata host in Ontario and western Québec}

To identify the host(s) of $C$. bipunctata in Ontario and western Québec we analysed the distribution, habitat, and prey preferences of putative host species. In the analysis we included species that are of similar size or larger than the newly discovered New Brunswick host species A. cleora (Banks). Specifically, we included species with an average female body length of at least $14 \mathrm{~mm}$ (see Table 2). The average female body length of $A$. cleora is $15 \mathrm{~mm}$ (Evans 1951).

Localities of potential host species were considered shared with $C$. bipunctata when locality names on specimen labels were the same. 
Table 1. Presence/absence of Ceropales bipunctata and its host Anoplius cleora at New Brunswick survey sites.

\begin{tabular}{|c|c|c|c|c|c|c|c|c|c|c|c|}
\hline $\begin{array}{l}\text { Site } \\
\text { number }\end{array}$ & Locality & Habitat & $\begin{array}{l}\text { Date (all } \\
\text { 2015) }\end{array}$ & Observer(s) & $\begin{array}{c}\text { Temperature } \\
\left({ }^{\circ} \mathrm{C}\right)\end{array}$ & $\begin{array}{c}\% \text { Cloud } \\
\text { cover }\end{array}$ & $\begin{array}{l}\text { Start time } \\
\text { (ADT) }\end{array}$ & $\begin{array}{l}\text { End time } \\
\text { (ADT) }\end{array}$ & Coordinates & $\begin{array}{c}\text { Ceropales } \\
\text { bipunctata } \\
\text { observed }\end{array}$ & $\begin{array}{c}\text { Anoplius } \\
\text { cleora } \\
\text { observed }\end{array}$ \\
\hline 1 & Eel River Bar & Sand/gravel bar & 02.ix & J.K., S.L.R. & 19 & 0 & 09:47 AM & $10: 25 \mathrm{AM}$ & $\begin{array}{l}48.0299^{\circ} \mathrm{N} \\
66.3703^{\circ} \mathrm{W}\end{array}$ & No & No \\
\hline 2 & Hamilton Point & Sand/gravel bar & 02.ix & J.K., S.L.R. & 20 & $\begin{array}{c}\text { Not } \\
\text { recorded }\end{array}$ & 10:50 AM & 11:24 AM & $\begin{array}{l}47.9914^{\circ} \mathrm{N}, \\
66.2660^{\circ} \mathrm{W}\end{array}$ & No & No \\
\hline 3 & $\begin{array}{l}\text { Little Belledune } \\
\text { Point }\end{array}$ & Gravel beach & 02.ix & J.K., S.L.R. & 25 & 0 & $12: 20 \mathrm{PM}$ & 12:59 PM & $\begin{array}{l}47.9199^{\circ} \mathrm{N} \\
65.8984^{\circ} \mathrm{W}\end{array}$ & No & No \\
\hline 4 & Petit-Rocher-Nord & Gravel beach & 02.ix & J.K., S.L.R. & 25 & $\begin{array}{l}\text { Not } \\
\text { recorded }\end{array}$ & 01:30 PM & 01:50 PM & $\begin{array}{l}47.8010^{\circ} \mathrm{N} \\
65.7270^{\circ} \mathrm{W}\end{array}$ & No & No \\
\hline 5 & Beresford Beach & Gravel beach & 02.ix & J.K., S.L.R. & 25 & 20 & 02:30 PM & 03:16 PM & $\begin{array}{l}47.7107^{\circ} \mathrm{N} \\
65.6984^{\circ} \mathrm{W}\end{array}$ & No & No \\
\hline 6 & Youghall Beach & Coastal sand dune & 26.viii & J.K., S.L.R. & 23 & 90 & 10:45 AM & 11:43 AM & $\begin{array}{l}47.6580^{\circ} \mathrm{N} \\
65.6224^{\circ} \mathrm{W}\end{array}$ & Yes & Yes \\
\hline 6 & Youghall Beach & Coastal sand dune & 02.ix & J.K., S.L.R. & 25 & 80 & 03:41 PM & 05:00 PM & $\begin{array}{l}47.6580^{\circ} \mathrm{N} \\
65.6224^{\circ} \mathrm{W}\end{array}$ & Yes & Yes \\
\hline 7 & Daly Point & Gravel beach & 26.viii & J.K., S.L.R. & 23 & 90 & 01:00 PM & 01:16 PM & $\begin{array}{l}47.6371^{\circ} \mathrm{N} \\
65.6243^{\circ} \mathrm{W}\end{array}$ & No & No \\
\hline 8 & East Bathurst & Sand/gravel bar & 26.viii & J.K., S.L.R. & 23 & 80 & 09:36 AM & 09:56 AM & $\begin{array}{l}47.6179^{\circ} \mathrm{N} \\
65.6395^{\circ} \mathrm{W}\end{array}$ & No & No \\
\hline 9 & Miscou Centre & Coastal sand dune & 01.ix & J.K., S.L.R. & 20 & 0 & 12:15 PM & 02:00 PM & $\begin{array}{l}47.9568^{\circ} \mathrm{N} \\
64.5657^{\circ} \mathrm{W}\end{array}$ & No & Yes \\
\hline 10 & Miscou Plains & Coastal sand dune & 01.ix & J.K., S.L.R. & 20 & 10 & 10:05 AM & 11:40 PM & $\begin{array}{l}47.9996^{\circ} \mathrm{N} \\
64.5497^{\circ} \mathrm{W}\end{array}$ & No & Yes \\
\hline 11 & Wilson Point & Coastal sand dune & 01.ix & J.K., S.L.R. & 18 & 50 & 02:20 PM & 03:00 PM & $\begin{array}{l}47.9334^{\circ} \mathrm{N} \\
64.4805^{\circ} \mathrm{W}\end{array}$ & Yes & Yes \\
\hline 12 & Chiasson & Coastal sand dune & 01.ix & J.K., S.L.R. & 18 & 0 & 03:53 PM & 04:28 PM & $\begin{array}{l}47.7257^{\circ} \mathrm{N} \\
64.6494^{\circ} \mathrm{W}\end{array}$ & Yes & Yes \\
\hline 13 & Green Point & Coastal sand dune & 19.viii & J.K. & 24 & 0 & 03:10 PM & 05:20 PM & $\begin{array}{l}47.6019^{\circ} \mathrm{N}, \\
64.8265^{\circ} \mathrm{W}\end{array}$ & No & No \\
\hline 13 & Green Point & Coastal sand dune & 03.ix & J.K., S.L.R. & 20 & 0 & 09:34 AM & 10:37 AM & $\begin{array}{l}47.6019^{\circ} \mathrm{N} \\
64.8265^{\circ} \mathrm{W}\end{array}$ & Yes & No \\
\hline 14 & $\begin{array}{l}\text { Val Comeau } \\
\text { Provincial Park }\end{array}$ & Coastal sand dune & 03.ix & J.K., S.L.R. & 20 & 0 & 11:20 AM & 11:53 AM & $\begin{array}{l}47.4680^{\circ} \mathrm{N}, \\
64.8727^{\circ} \mathrm{W}\end{array}$ & Yes & Yes \\
\hline
\end{tabular}


Of course, this is not necessarily the case, especially for old material where locality information is often approximate. In some cases localities were considered shared when they were in immediate vicinity to each other (e.g., Turkey Point Provincial Park and Turkey Point Tract). This was only done for well-known sites where we know that habitat is continuous between sites. General habitat information (as recorded in Table 3) was inferred from the literature and/or specimen data.

\section{Acronyms of collections}

We examined specimens and/or gathered distribution data from the following collections:

CNCI - Canadian National Collection of Insects, Ottawa, Ontario, Canada

DEBU - University of Guelph Insect Collection, Guelph, Ontario, Canada

LEMQ - Lyman Entomological Museum, McGill University, Ste-Anne-de-Bellevue, Québec, Canada

NBMB - New Brunswick Museum, Saint John, New Brunswick, Canada

NSPM - Nova Scotia Museum, Halifax, Nova Scotia, Canada

ROME - Royal Ontario Museum Insect Collection, Toronto, Ontario, Canada

\section{Results}

\section{Range and habitat preference}

Ceropales bipunctata was found at 21 of the 33 sites surveyed (see Fig. 2). The species occurred along the entirety of New Brunswick's Gulf of Saint Lawrence Coast, and one site on Chaleur Bay. Ceropales bipunctata was present at $81 \%$ of surveyed dunes sites $(n=26)$. The species was not found at any gravel beaches $(n=4)$ or sand/ gravel bars $(n=3)$ studied. We suspect these habitat types are not suitable for $C$. bipunctata or its host(s) (see host discussion below).

Dunes where $C$. bipunctata was found $(n=21)$ range from very large (e.g., dunes in the Tracadie area extend over $50 \mathrm{~km}$ ) to small (e.g., the dune at Bar-de-Cocagne is $<500 \mathrm{~m}$ long). Dune sites that lacked $C$. bipunctata $(n=5)$ showed no obvious differences from dunes where the species was present; however, no detailed assessment of dune characteristics was conducted. 
Fig. 2. 2015 survey sites with historic and recent Ceropales bipunctata localities in the Maritimes. Locality numbers listed in Table 1.

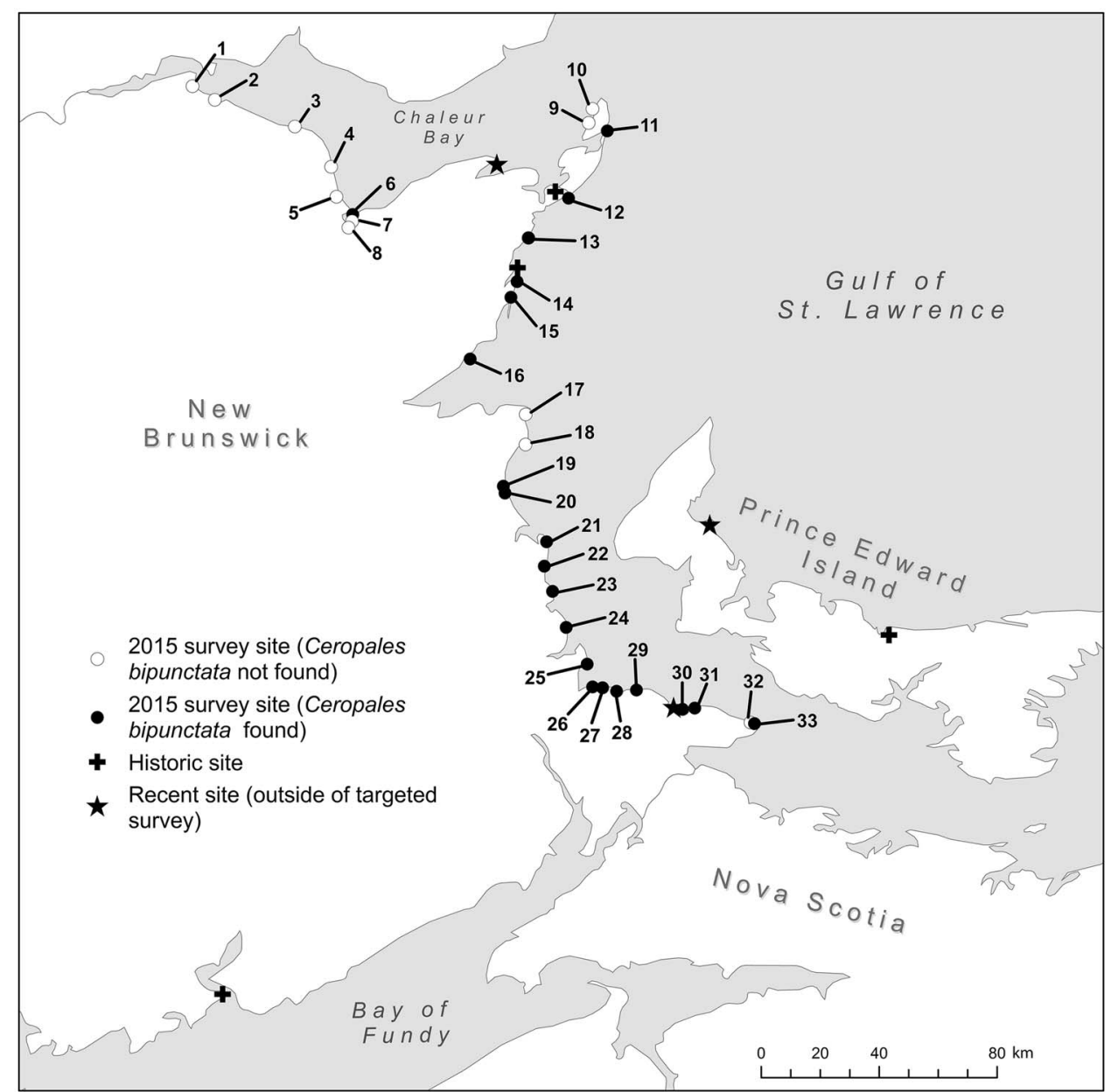

\section{Hosts of Ceropales bipunctata and their spider prey in New Brunswick}

We observed $C$. bipunctata parasitising the prey of another spider wasp on three occasions: one each at Cap Lumière, Petit-Chockpish, and Parlee Beach. Each time a group of four to six C. bipunctata were seen swarming a spider wasp that was dragging a subdued spider (Fig. 3). The host wasps from Petit-Chockpish and Cap Lumière were both collected and later identified as A. cleora; the host wasp at Parlee Beach was not collected or identified. The spider prey was collected in all three cases and identified as adult females of Arctosa littoralis (Hentz) (Araneae: Lycosidae). At least one swarm included a male of
C. bipunctata (Cap Lumière). At Cap Lumière one female of the swarm landed and apparently oviposited on the spider prey during transport (Fig. 4). At Petit-Chockpish the host was observed pulling the spider into a previously dug burrow. Shortly thereafter a female $C$. bipunctata also entered the burrow, presumably to oviposit on the spider. After a minute or two C. bipunctata exited the burrow while the host remained inside. We then excavated the burrow and retrieved both host and prey. At Cap Lumière and Parlee Beach the pursued hosts showed aggressive behaviour towards $C$. bipunctata. They briefly left their spider prey and flew at the parasites, presumably in an attempt to drive them away. 
Table 2. Localities shared between Ceropales bipunctata and potential host species in Ontario and western Québec.

\begin{tabular}{|c|c|c|c|c|c|c|c|c|}
\hline Species & \multicolumn{4}{|c|}{ Localities } & List of shared localities & \multicolumn{3}{|c|}{ Body length (ㅇ) } \\
\hline Ceropales bipunctata & 24 & 11 & & & See below under each species & 10.3 & 12.6 & 11.2 \\
\hline Anoplius (Lophopompilus) atrox & 9 & 4 & 3 & 1 & Chatham, Point Pelee, Toronto, Turkey Point (see also Fig. 6) & 15 & 24 & 20 \\
\hline $\begin{array}{l}\text { Anoplius (Arachnophroctonus) } \\
\text { semicinctus }\end{array}$ & 25 & 3 & 1 & 2 & Point Pelee, Toronto, Turkey Point & 11 & 20 & 15.5 \\
\hline Anoplius (Lophopompilus) cleora & 23 & 2 & & 1 & Point Pelee, Toronto (see also Fig. 7) & $13^{\dagger}$ & $19^{\dagger}$ & 15 \\
\hline $\begin{array}{l}\text { Anoplius (Lophopompilus) } \\
\text { bengtssoni }\end{array}$ & 9 & 2 & & 1 & Point Pelee, Toronto & 17 & 26 & 22 \\
\hline Tachypompilus ferrugineus & 7 & 2 & & & Chaffey's Lock, Point Pelee & 15 & 22 & 18 \\
\hline Entypus unifasciatus & 12 & 1 & 1 & & Chatham & 19 & 21 & 20 \\
\hline
\end{tabular}

Total: number of localities where the species has been collected. Shared: number of localities shared between C. bipunctata and potential hosts. Same day: number of localities where a species was collected on the same day as $C$. bipunctata. Same week: number of localities where a species was collected within seven days from $C$. bipunctata (excluding collecting events that overlap those from previous column). Underlined are localities where $C$. bipunctata has been collected since 2000. Body length measurements according to Evans (1950, 1951), Kurczewski and Kiernan (2015) and this study (C. bipunctata only, $n=9)$.

* See also note below Figure 5

Anoplius cleora collected by us in New Brunswick were smaller, ranging from 10-15 mm. 
Table 3. Prey and nest sites of potential host species of Ceropales bipunctata in Ontario and western Québec.

\begin{tabular}{|c|c|c|c|}
\hline Species & Prey & Nest sites & Host \\
\hline $\begin{array}{l}\text { Anoplius (Lophopompilus) } \\
\text { aethiops }\end{array}$ & Lycosidae & $\begin{array}{l}\text { Abandoned, overgrown } \\
\text { fields and woodland } \\
\text { edges }\end{array}$ & $\begin{array}{l}\text { Yes (ON, QC), likely } \\
\text { (Maritimes non- } \\
\text { dune) }\end{array}$ \\
\hline Anoplius (Lophopompilus) atrox & Lycosidae, Pisauridae & $\begin{array}{l}\text { Abandoned, overgrown } \\
\text { fields and woodland } \\
\text { edges }\end{array}$ & Very likely $(\mathrm{ON})$ \\
\hline Anoplius (Lophopompilus) cleora & Lycosidae & Sandy habitats near water & Yes (Maritimes dunes) \\
\hline $\begin{array}{l}\text { Anoplius (Lophopompilus) } \\
\text { bengtssoni }\end{array}$ & $\begin{array}{l}\text { Unknown (probably } \\
\text { Lycosidae, perhaps } \\
\text { Pisauridae) }\end{array}$ & $\begin{array}{l}\text { Savannas, sandy fields - } \\
\text { crepuscular/nocturnal } \\
\text { habits }\end{array}$ & Very unlikely \\
\hline $\begin{array}{l}\text { Anoplius (Arachnophroctonus) } \\
\quad \text { nigritus }\end{array}$ & $\begin{array}{l}\text { Mostly Lycosidae, also } \\
\text { Agelenidae }\end{array}$ & Sandy habitats & Very unlikely \\
\hline $\begin{array}{l}\text { Anoplius (Arachnophroctonus) } \\
\text { semicinctus }\end{array}$ & Lycosidae & Sandy habitats & Very unlikely \\
\hline Tachypompilus ferrugineus & Lycosidae, Pisauridae & $\begin{array}{l}\text { Rock piles, crevices in } \\
\text { stone walls and } \\
\text { buildings }\end{array}$ & Unlikely \\
\hline Entypus unifasciatus & Lycosidae, Pisauridae & $\begin{array}{l}\text { Abandoned, overgrown } \\
\text { fields and woodland } \\
\text { edges }\end{array}$ & Unlikely \\
\hline Poecilopompilus algidus & Araneidae & $\begin{array}{l}\text { Savannas, overgrown } \\
\text { fields }\end{array}$ & Unlikely \\
\hline Poecilopompilus interruptus & Araneidae & $\begin{array}{l}\text { Fields with bare sandy and } \\
\text { gravelly openings, sand/ } \\
\text { gravel pits near woodland }\end{array}$ & Unlikely \\
\hline Anoplius (Anoplius) depressipes & Pisauridae & $\begin{array}{l}\text { Shores of ponds, swamps, } \\
\text { lagoons, slow-moving } \\
\text { streams (habitat } \\
\text { specialist) }\end{array}$ & Very unlikely \\
\hline
\end{tabular}

Note: Prey and nest sites based on observations in the Great Lakes region (see Kurczewski and Kiernan 2015); prey information for $P$. algidus from Kurczewski and Edwards (2012); habitat information for A. bengtssoni and P. algidus extrapolated from specimen locality data.

Fig. 3. Four Ceropales bipunctata (marked with white dots) swarming a female of Anoplius cleora (black dot) and its prey, Arctosa littoralis (Cap Lumière, New Brunswick, 20 August 2015).

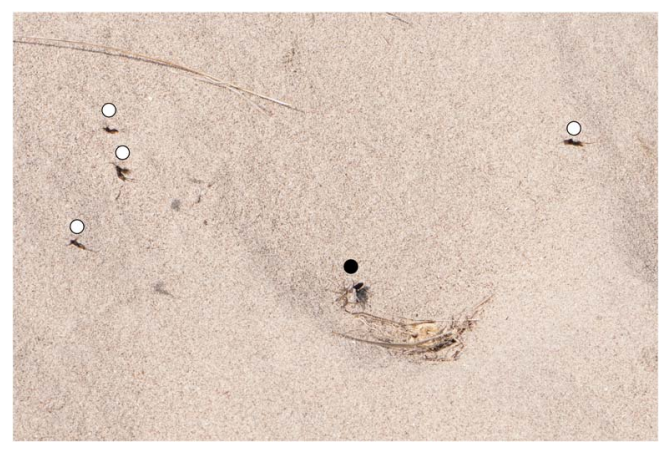

Fig. 4. Ceropales bipunctata ovipositing on an Arctosa littoralis captured by Anoplius cleora (Cap Lumière, New Brunswick, 20 August 2015).

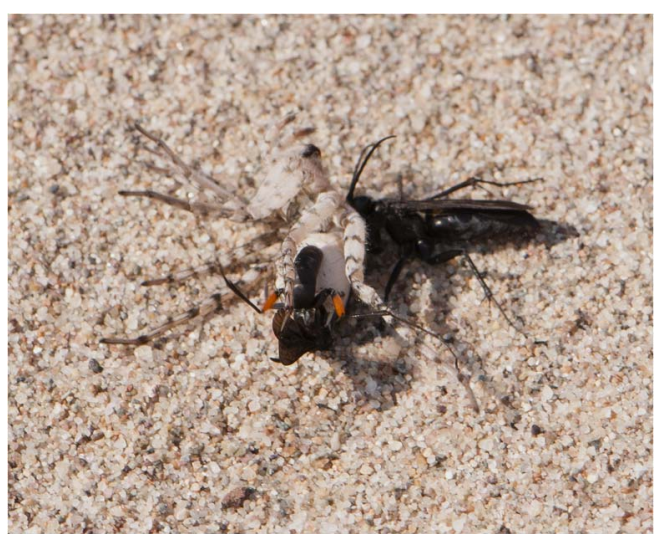




\section{Co-occurrence of Ceropales bipunctata and potential host species in Ontario and western Québec}

A total of 11 species of non-parasitic Pompilidae in Ontario and western Québec are large enough to be potential hosts of $C$. bipunctata (Table 2) including five species that are new records for Canada (M.B., unpublished): Anoplius bengtssoni (Regan), A. depressipes Banks, Entypus unifasciatus (Say), Poecilopompilus algidus (Smith), and Tachypompilus ferrugineus (Say). Ceropales bipunctata is known from 24 localities in Ontario and western Québec, 11 of which are shared with one or more of the potential host species. Anoplius aethiops is present at 10 of the latter (Fig. 5), Anoplius atrox (Dahlbom) at four (Fig. 6). The remaining nine species share three or less localities each with $C$. bipunctata. Remarkably, the New Brunswick host species A. cleora is widely distributed in dune habitats around the Great Lakes but shares only two localities with $C$. bipunctata (Fig. 7). Unlike the New Brunswick population, C. bipunctata is largely absent from dune sites in this part of its range.

The strong correlation between A. aethiops and C. bipunctata is furthermore underlined by the fact that $A$. aethiops is the only potential host species whose range completely overlaps with that of $C$. bipunctata in Ontario and western Québec. None of the other species have ever been recorded from Québec. Two species (Entypus unifasciatus and Poecilopompilus interruptus (Say)) have a Carolinian distribution and are restricted to southwestern Ontario. The correlation between $A$. aethiops and C. bipunctata also has a temporal dimension (Table 2). At three localities (Bobcaygeon, Chatham, and Toronto) the two species were collected on the same day; at another two they were collected within a week from each other (De Grassi Point and Ottawa). A strong correlation was also observed between $A$. atrox and C. bipunctata, which were collected on the same day at three different localities (Chatham, Point Pelee, and Toronto).

\section{Maritimes records of Ceropales bipunctata and its hosts from sources other than the present survey}

\section{Ceropales bipunctata}

New Brunswick: Saint John, 5 August 1901, A.G. Leavitt, NBMB (unpublished); Shippagan, 28

Fig. 5. Occurrence of Ceropales bipunctata and Anoplius aethiops in Ontario and western Québec (see also Table 2). Anoplius aethiops is considered to be the primary host of $C$. bipunctata in Ontario and western Québec (see Discussion). Note: the LEMQ has specimens identified as A. aethiops from Montréal (potentially shared with C. bipunctata) and Lévis, Québec. They are not included in the map because we were unable to confirm their identity.

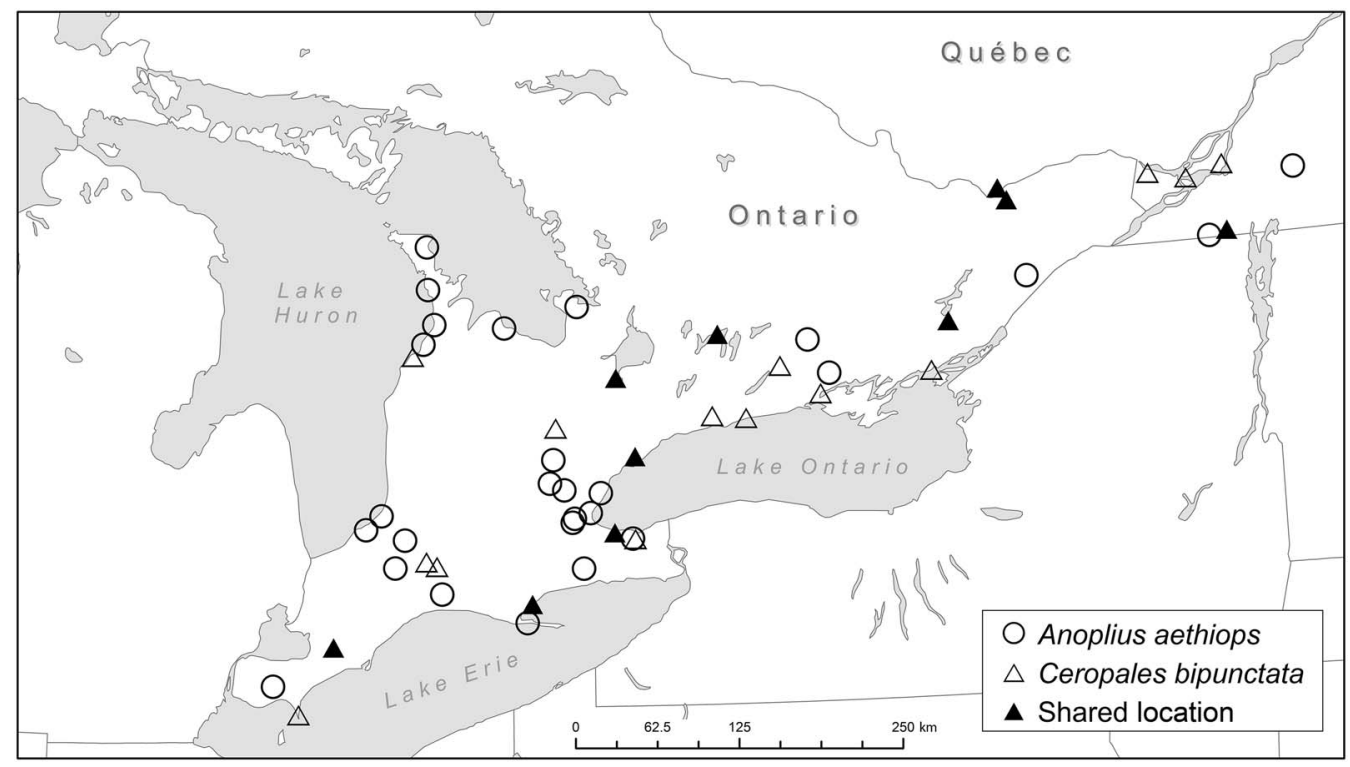


Fig. 6. Occurrence of Ceropales bipunctata and Anoplius atrox in Ontario and western Québec (see also Table 2). Anoplius atrox is considered to be a likely secondary host of C. bipunctata in southwestern Ontario (see Discussion).

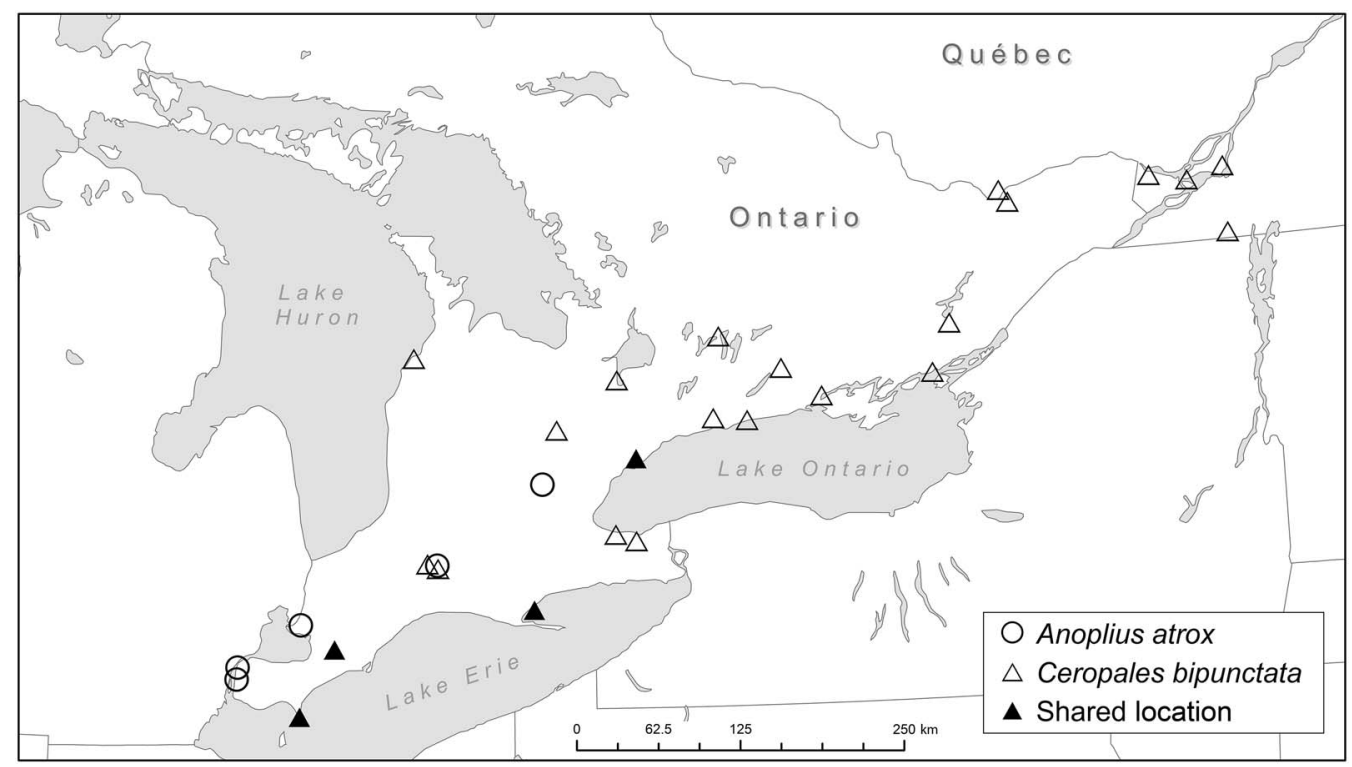

Fig. 7. Occurrence of Ceropales bipunctata and Anoplius cleora in Ontario and western Québec (see also Table 2). Anoplius cleora is ruled out as a host of C. bipunctata in this part of the range (see Discussion).

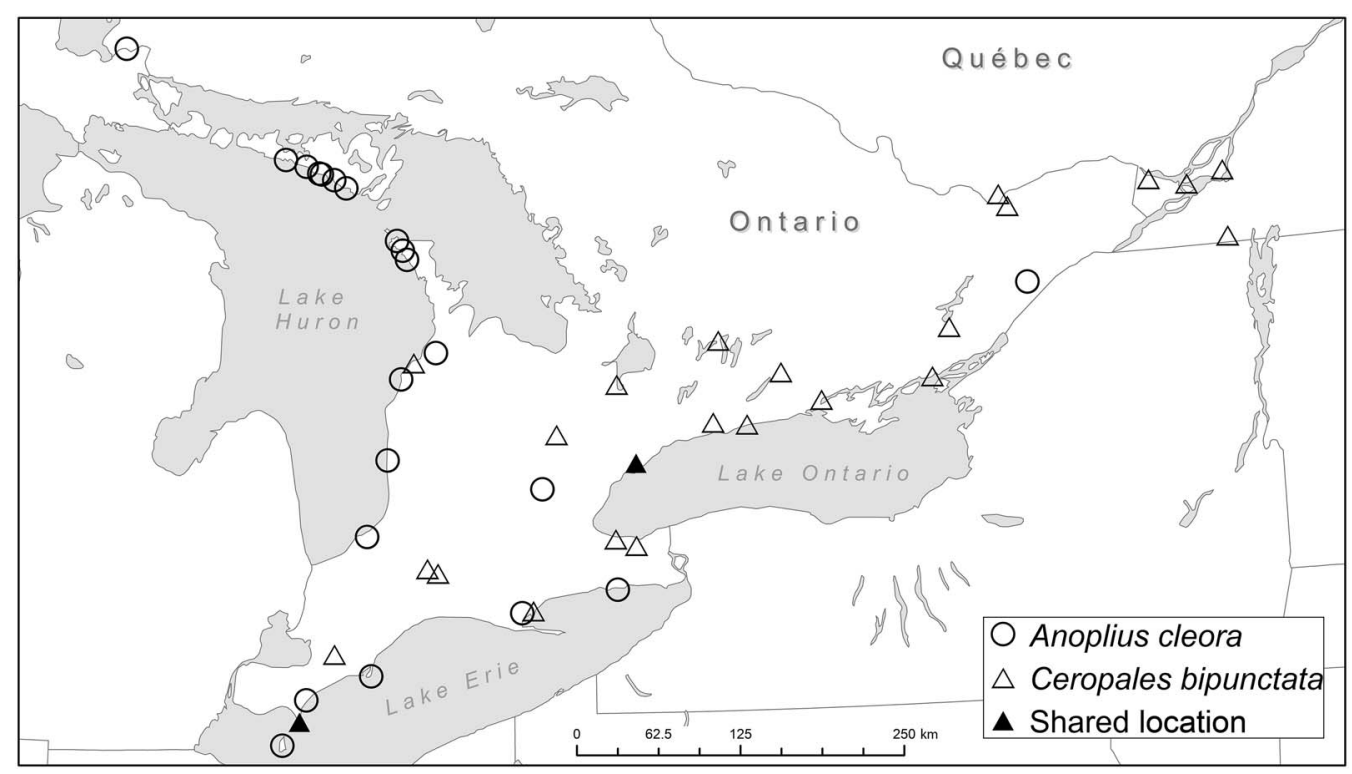

July 1939, J. McDunnough, CNCI (Townes 1957; Godsoe 2004); Tracadie, 30 July 1939, J. McDunnough, CNCI (Townes 1957; Godsoe
2004); Petit-Cap dune, $46.1801^{\circ} \mathrm{N}, 64.1407^{\circ} \mathrm{W}, 7$ September 2012 and 6 August 2013, S. Tingley, photographic records (Tingley 2012, 2013); 
Maisonette dune, $47.8253^{\circ} \mathrm{N}, 64.9776^{\circ} \mathrm{W}, 30$ July and 5 August 2012, S. Tingley, photographic records (Tingley 2012). Prince Edward Island: Brackley Beach, 14 July 1940, J. McDunnough, CNCI (Townes 1957; Godsoe 2004); Conway Sandhills, $46.7383^{\circ} \mathrm{N}, 63.9919^{\circ} \mathrm{W}, 18$ September 2015, S.L. Robinson, NBMB (unpublished).

Anoplius cleora (confirmed host)

New Brunswick: Chatham, 15 August 1926, F. Johansen, CNCI (Evans 1951); Tracadie, 22 July 1939, J. McDunnough, CNCI (unpublished). Nova Scotia: Sable Island, West Light, 10 August 1969, F.W. Scott, NSPM (Wright 1989); two specimens, Sable Island, Meteorological Station, 23 July 1976 and 1977, B. Wright, NSPM (unpublished); Mitchells Island, $45.8941^{\circ} \mathrm{N}, 63.7971^{\circ} \mathrm{W}, 2016$, J. Klymko, NBMB (unpublished). Prince Edward Island: two specimens, Brackley Beach, "Can. Nat. Park", 24 and 30 July 1940, J. McDunnough, CNCI (cited incompletely by Evans 1951); five specimens, Dalvay House, "Can. Nat. Park", 19 and 21 July 1940, J. McDunnough, CNCI (cited incompletely by Evans 1951).

Anoplius aethiops (potential host, see Discussion)

New Brunswick: Saint John, 2 September 1900, P.R. McIntosh, NBMB (unpublished); Saint John, 15 September 1902, A.G. Leavitt, NBMB (unpublished). Nova Scotia: three specimens, Kentville, 7, 21, and 22 August 1915, CNCI (Evans 1951).

\section{Ontario and Québec records of Ceropales} bipunctata not included in Godsoe (2004)

Ontario: two specimens, Leeds and Grenville County, Chaffeys Locks, Queens University Biological Station, 1-4 August 2005, on Solidago, L. Best, DEBU (unpublished); Bruce County, MacGregor Point Provincial Park near Sunset Point, 7 August 2011, dead on trail, S.M. Paiero, DEBU (unpublished); Haldimand-Norfolk Region, Turkey Point Provincial Park, $42.7117^{\circ} \mathrm{N}, 80.3422^{\circ} \mathrm{W}$, 3-28 August 2009, open sandy field, malaise trap, S.M. Paiero, DEBU (unpublished); HaldimandNorfolk Region, Turkey Point Provincial Park, site $2,42.7078^{\circ} \mathrm{N}, 80.3414^{\circ} \mathrm{W}, 17$ August 2011, savannah, S.M. Paiero, DEBU (unpublished). Québec: Rigaud (Townes 1957); Ste-Anne-deBellevue, 28 August 1931, LEMQ (unpublished); two specimens, Montréal, 13 August 1922 and 22 August 1925, J.W. Buckle, LEMQ (unpublished).

\section{Discussion}

\section{The host of Ceropales bipunctata in New Brunswick dune habitat}

This is the first time a host of $C$. bipunctata has been documented. Little is known about the hosts of Ceropales Latreille species in general, with information being available on just three of the 14 Nearctic species (Krombein 1979). The most common and widespread species, the Holarctic C. maculata (Fabricius), appears to have a wide host spectrum that includes two records from different subfamilies (Pompilinae: Arachnospila scelesta (Cresson) and Pepsinae: Priocnemis Schiødte, species unidentified). The other two species both have hosts in the subfamily Pepsinae (C. hatoda Brimley: Ageniella mintaka Brimley and $C$. robinsonii Cresson: Phanagenia bombycina (Cresson)). Note that Krombein (1979) and other authors misapplied the name Ageniella partita Banks to A. mintaka before Evans (1995). The newly recorded host of C. bipunctata, A. cleora, belongs in the subfamily Pompilinae. Ceropales bipunctata is one of the largest species in its genus (fore wing length 10-16 mm, see Townes 1957), which rules out most of the other pompilid species from our survey sites as potential hosts. The only species of comparable size besides A. cleora was Evagetes ingenuus (Cresson), itself a cleptoparasite. There are no published host records for the latter but it seems highly likely that it also parasitises A. cleora in our survey area. Episyron biguttatus (Fabricius), a common species at our sites, is typically smaller than A. cleora, and therefore a less likely host. Based on these observations it appears as though A. cleora is the only host of C. bipunctata on dune sites in the survey area.

Anoplius cleora belongs in the subgenus Lophopompilus Radoszkowski, which includes some of the largest species in the genus. It is associated with open sand habitats, mostly near bodies of water, and ranges from southern Canada to southern Mexico (Evans 1951, 1966; Kurczewski and Kiernan 2015). The species was widespread in the dunes surveyed (present at 19 of the 26 dune sites, see Table 1). The apparent absence of this species at seven dune sites is probably due to inadequate sampling effort since $C$. bipunctata was the main focus of our study. Anoplius cleora was not collected at the gravel 
beaches and gravel bars on Chaleur Bay, likely because suitable open sand substrate was lacking.

The spider A. littoralis is one of the main prey species of Anoplius cleora, representing up to 97\% of prey taken in the eastern Great Lakes Region (Kurczewski and Kiernan 2015). This species is also widespread in sandy habitats, ranging from southern Canada to Panama (Dondale and Redner 1990).

\section{Distribution of Ceropales bipunctata in the Maritimes}

Our data show that $C$. bipunctata is widespread and common in dune habitat along New Brunswick's Gulf of Saint Lawrence Coast. An additional historic record from Saint John, where dunes are absent, is discussed below. Ceropales bipunctata and A. cleora are each known from two localities on Prince Edward Island (see above). Considering how much dune habitat exists on Prince Edward Island, both species are likely widespread there. There are no published records of $C$. bipunctata from Nova Scotia, and a search for material at the New Brunswick and the Nova Scotia Museums failed to produce any new records. Anoplius cleora is known from Sable Island and western mainland Nova Scotia (see above). It is likely that $A$. cleora is widespread in Nova Scotia dune habitat, and that $C$. bipunctata will be discovered there in future.

\section{Conservation status of Ceropales bipunctata in the Maritimes}

The predominant long-term threat to C. bipunctata in the Maritimes is probably loss of dune habitat due to sea-level rise and coastal development. Coastal dunes grow, shrink, and shift because of natural and anthropogenic causes (Nordstrom et al. 1990). A study in southeastern New Brunswick detected net losses of dune and beach habitat from $8-33 \%$ at five separate study sites between 1944 and 2001 (Hanson et al. 2006).

Sea-level rise can result in loss of dunes when barriers prevent landward migration (Feagan et al. 2005; O'Carroll et al. 2006). Sea rise projections between 2000 and 2100 for New Brunswick's Gulf of St. Lawrence Coast range between 50 and $60 \mathrm{~cm}$ (Forbes et al. 2006). This will accelerate dune migration and will result in habitat loss where coastal development prevents this movement. Decreasing coverage of sea ice may exacerbate this trend through beach erosion during winter storms as sea ice has a dampening effect on wave formation (Parkes et al. 2006).

\section{Putative hosts of Ceropales bipunctata in Ontario, western Québec, and non-dune sites in the Maritimes}

The comparison of locality data of C. bipunctata and potential hosts leads to three conclusions: (1) The New Brunswick host Anoplius cleora can be ruled out as host in Ontario and western Québec; (2) Anoplius aethiops is hypothesised to be the primary host of C. bipunctata in Ontario and western Québec; (3) the absence of A. aethiops from Point Pelee points to the existence of at least one secondary host in Ontario with A. atrox as the most likely candidate. (1) Ceropales bipunctata and A. cleora show minimal locality overlap in southwestern Ontario (Fig. 7). Historically, both species occurred together at Point Pelee and in Toronto. However, the overlap between the two species in Toronto is tenuous, with A. cleora having been collected there only once (one female, 9 August 1888, ROME). At Point Pelee, A. cleora occurs up to the present (last record from 2003, DEBU) whereas $C$. bipunctata was last collected in 1954 (Godsoe 2004). Anoplius cleora occurs mostly along the shores of Lake Huron and Lake Erie, where significant dune sites are located. Ceropales bipunctata, on the other hand, occurs mostly at interior sites or at lakeshore sites that are not sandy. We conclude that A. cleora is not a suitable host for Great Lakes populations of C. bipunctata. Otherwise, it would be inexplicable why the latter is absent from Great Lakes dunes, the primary habitat in New Brunswick. (2) The high geographic and temporal overlap between C. bipunctata and A. aethiops leaves little doubt that the latter is the primary host of $C$. bipunctata in Ontario and western Québec. This is not surprising since $A$. aethiops is closely related to A. cleora, and both species prey on Lycosidae (Table 3). (3) It can be assumed that the lack of records of $A$. aethiops from Point Pelee reflects a true absence of the species. Over the course of a century, a multitude of entomologists collected a significant number of spider wasps at Point Pelee, especially during the years 1920 (material at ROME); 1954 (material at CNCI); 1978-1983, 
1999-2000, and 2003 (material at DEBU). It seems unlikely that a large and conspicuous species like A. aethiops would have been missed. With A. cleora being ruled out as a potential host in Ontario (as discussed above), the most likely alternative host is A. atrox (see Table 2). This species was collected at Point Pelee on the same day by the same collector as C. bipunctata (one female, 23 August 1920, N.K. Bigelow, ROME). Like A. aethiops, A. atrox is a close relative of $A$. cleora. Unlike the other two species it preys on Pisauridae in addition to Lycosidae (Table 3). Other pompilid species are far less likely to be hosts. Anoplius nigritus (Dahlbom) and A. semicinctus (Dahlbom) (both in the subgenus Arachnophroctonus Howard) are restricted to sandy habitats unlike $C$. bipunctata. Anoplius bengtssoni, a close relative of $A$. atrox, has mainly crepuscular/nocturnal habits (Kurczewski and Kiernan 2015), making it largely inaccessible as for parasitisation. Tachypompilus ferrugineus (Say) preys on similar spiders as the Anoplius hosts but it uses different nest sites and belongs to a different genus (Table 3). It was only recently discovered at Point Pelee (one specimen, 2003, DEBU), almost half a century after $C$. bipunctata was last collected there (Godsoe 2004). Poecilopompilus algidus and $P$. interruptus prey on orb-weaving spiders (Araneidae) unlike the other hosts of $C$. bipunctata. Entypus unifasciatus, another predator of Lycosidae, is in a different subfamily (Pepsinae). Anoplius depressipes, which has flattened tarsi enabling it to pursue fishing spiders (Pisauridae) on the water surface, is restricted to habitats near water.

The historic occurrence of $C$. bipunctata at Saint John, New Brunswick (see above), deserves special consideration. The area is devoid of dunes, and there are no known records of A. cleora, though the gravel and sand tombolo associated with "Taylors Island", just west of Saint John, may offer suitable habitat. However, three specimens of A. aethiops were collected at Saint John around the same time as $C$. bipunctata (one female, one male, 3 September 1900, P.R. McIntosh, and one female, 15 September 1902, A.G. Leavitt, all NBMB). This suggests that A. aethiops could be a host for C. bipunctata at non-dune sites in the Maritimes. Further study is required since it cannot be ruled out that $A$. cleora might also be present. No other records of A. aethiops are known from New Brunswick, but given the paucity of survey effort in the region it remains unclear how widespread A. aethiops was or is in the province. Elsewhere in the Maritimes, A. aethiops has been recorded from Kentville, Nova Scotia (three specimens from August 1915, no collector mentioned, CNCI; see also Evans 1951).

\section{The decline of Ceropales bipunctata in Ontario and western Québec}

Godsoe (2004) proposed that the decline of C. bipunctata may have been driven by a decline of its host species. The present data allows us to test this hypothesis. As discussed above, C. bipunctata appears to use different hosts within its Canadian range: A. cleora in dune habitats of the Maritimes, A. aethiops in Ontario, western Québec, and possibly non-dune habitat of New Brunswick, and A. atrox, a likely secondary host in southwestern Ontario. Anoplius cleora is at present widely distributed throughout shoreline dune habitats of New Brunswick and the Great Lakes. Consistent with Godsoe's hypothesis, C. bipunctata is doing well in New Brunswick dune habitat, where this species is being used as a host. In Ontario and western Québec, where Anoplius aethiops is the inferred primary host, the situation is very different. Both parasite and host formerly had robust populations there, but are currently close to extirpation (Fig. 8) ${ }^{1}$. Only two specimens of $A$. aethiops have been deposited in collections since 2000 (one specimen, Turkey Point Tract, 17 August 2003; one specimen, Queens University Biological Station, Chaffey's Lock, 13-18 August 2006; both DEBU). This is quite extraordinary considering that some of us (M.B. and co-workers at University of Guelph) were dedicating considerable effort on collecting aculeate wasps in Ontario. This recent rarity contrasts with significant numbers of specimens collected from 1888 to 1896 in Toronto (by W.M. Brodie; ROME, CNCI) and 1912 to 1920 in the Ottawa

\footnotetext{
${ }^{1}$ The same is likely true for non-dune populations of C. bipunctata and A. aethiops in the Maritimes. The only known records are from 1900 to 1915 (see above). More research is needed to ascertain the host relationships and status of non-dune populations in the Maritimes.
} 
Fig. 8. Ceropales bipunctata and potential host species: number of specimens from Ontario and western Québec deposited per decade. Explanations: data for C. bipunctata updated after Godsoe (2004), data for Anoplius species based on material at CNCI, DEBU, and ROME.

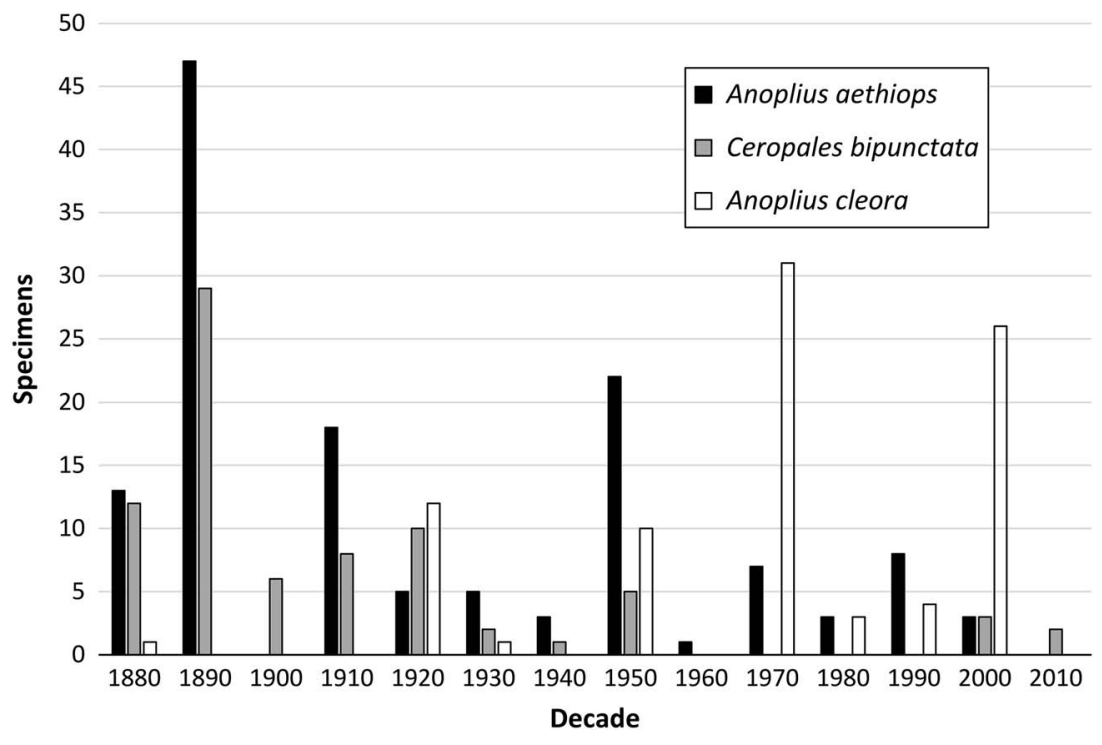

area (by F.W.L. Sladen and others, CNCI). These time periods also happen to be among the most productive for collecting $C$. bipunctata. The status of $A$. atrox, a likely secondary host in southwestern Ontario, is similar to A. aethiops. Most of the material (24 specimens) was collected between 1890 and 1920 (at ROME, CNCI, DEBU) whereas only two specimens have been collected since 2000 (at DEBU). The different fate of C. bipunctata in Ontario/Québec versus the Maritimes strongly supports the hypothesis that the decline in Ontario and western Québec is indeed driven by a decline of its hosts.

The cause of decline of A. aethiops and A. atrox is unclear and warrants further study. Both species inhabit old fields, meadows, forest edges, and prairies (Evans 1951; Kurczewski and Kiernan 2015). The loss of unimproved farmland and prairie habitat may be a factor that contributed to their decline in Ontario or Québec. Another parameter that could be influential is the availability of large cursorial spiders (Lycosidae, and perhaps Pisauridae) that are used as prey by these species.

\section{Outlook}

The results of this study bring up a number of interesting new questions. What are the preferred hosts of $C$. bipunctata in other parts of its range? Is there a similar difference in host specialisation between coastal and interior populations in the United States of America? Do dune and non-dune populations of the Canadian Maritimes represent different host races, or are they part of a single host race that has a broader host spectrum than Ontario/Québec populations? How much are the host races of $C$. bipunctata differentiated genetically? A strong genetic differentiation would place further emphasis on conservations efforts for endangered host races.

\section{Conservation status of Ceropales bipunctata in Canada}

The results of this survey demonstrate that C. bipunctata is not at risk of extirpation from New Brunswick, or therefore Canada, in the foreseeable future. As a result, $C$. bipunctata has been moved from COSEWIC's high-priority candidate list to its low-priority candidate list. It is recommended, however, that $C$. bipunctata and its hosts be assessed at the provincial level by the Committee on the Status of Species at Risk in Ontario (COSSARO), as the strong evidence of decline in Ontario may warrant listing the species on the Ontario Endangered Species Act. 


\section{Acknowledgements}

Our field survey was funded by the New Brunswick Wildlife Trust Fund. Eric Tremblay arranged collecting permits for Kouchibouguac National Park of Canada. Stuart Tingley provided information about his observations of $C$. bipunctata in New Brunswick. Steven Paiero, Stephen Marshall (University of Guelph), Stéphanie Boucher, Terry Wheeler (Lyman Entomological Museum), Katherine Ogden (Nova Scotia Museum), and Sophie Cardinal (Canadian National Collection of Insects) kindly provided data on spider wasps from their collections. Brad Hubley and Chris Darling (Royal Ontario Museum) made Anoplius specimens from their collection available for verification. Andrew Hebda provided access to the Nova Scotia Museum insect collection. Donald F. McAlpine provided access to the New Brunswick Museum insect collection. Sean Blaney reviewed an earlier draft of this manuscript.

\section{Supplementary material}

To view supplementary material for this article, please visit https://doi.org/10.4039/tce.2017.40.

\section{References}

Dondale, C.D. and Redner, J.H. 1990. The insects and arachnids of Canada. The wolf spiders, nurseryweb spiders, and lynx spiders of Canada and Alaska (Araneae: Lycosidae, Pisauridae, and Oxyopidae). Agriculture Canada Publication 1856. The Insects and Arachnids of Canada, 17: 1-383.

Evans, H.E. 1950. A taxonomic study of the Nearctic spider wasps belonging to the tribe Pompilini (Hymenoptera: Pompilidae). Part I. Transactions of the American Entomological Society, 75: 133-270.

Evans, H.E. 1951. A taxonomic study of the Nearctic spider wasps belonging to the tribe Pompilini (Hymenoptera: Pompilidae). Part II. Genus Anoplius Dufour. Transactions of the American Entomological Society, 76: 207-361.

Evans, H.E. 1966. A revision of the Mexican and Central American spider wasps of the subfamily Pompilinae (Hymenoptera: Pompilidae). Memoirs of the American Entomological Society, 20: 1-442.

Evans, H.E. 1995. Notes and descriptions of Nearctic Ageniella (Hymenoptera, Pompilidae). Journal of the Kansas Entomological Society, 68: 451-460.

Feagan, R.A., Sherman, D.J., and Grant, W.E. 2005. Coastal erosion, global sea-level rise, and the loss of sand dune plant habitats. Frontiers in Ecology and the Environment, 3: 359-364.
Forbes, D.L., Parkes, G.S., and Ketch, L.A. 2006. Sea-level rise and regional subsidence. In The impacts of sea level rise and climate change on the coastal zone of southeastern New Brunswick. Environment Canada, New Brunswick, Canada. Pp. 34-94.

Godsoe, W. 2004. Evidence for the extirpation of Ceropales bipunctata Say (Hymenoptera: Pompilidae) in Ontario. Journal of the Entomological Society of Ontario, 134: $135-140$.

Hanson, A., Forbes, D., Bérubé, D., O'Carroll, S., Mahoney, M., Ollerhead, J., et al. 2006. Ecosystem impacts. In The impacts of sea level rise and climate change on the coastal zone of southeastern New Brunswick. Environment Canada, New Brunswick, Canada. Pp. 402-485.

Krombein, K.V. 1979. Superfamily Pompiloidea. In Catalog of Hymenoptera in America north of Mexico. Volume 2 Apocrita (Aculeata). Edited by K.V. Krombein, P.D. Hurd, D.R. Smith, and B.D. Burks. Smithsonian Institution Press, Washington, District of Columbia, United States of America. Pp. 1523-1571.

Kurczewski, F.E. and Edwards, G.B. 2012. Hosts, nesting behavior, and ecology of some North American spider wasps (Hymenoptera: Pompilidae). Southeastern Naturalist, 11(Monograph 4): $1-71$.

Kurczewski, F.E. and Kiernan, D.H. 2015. Analysis of spider wasp host selection in the eastern Great Lakes region (Hymenoptera: Pompilidae). Northeastern Naturalist, 22(Monograph 11): 1-88.

Nordstrom, K., Psuty, N., and Carter, B. 1990. Coastal dunes: form and process. John Wiley and Sons, Toronto, Ontario, Canada.

O'Carroll, S., Bérubé, D., Forbes, D.L., Hanson, A., Jolicoeur, S., and Fréchette, A. 2006. Coastal erosion. In The impacts of sea level rise and climate change on the coastal zone of southeastern New Brunswick. Environment Canada, New Brunswick, Canada. Pp. 324-401.

Parkes, G.S., Manson, G.K., Chagnon, R., and Ketch, L.A. 2006. Storm-surge, wind, wave and ice climatology. In The impacts of sea level rise and climate change on the coastal zone of southeastern New Brunswick. Environment Canada, New Brunswick, Canada. Pp. 95-262.

Tingley, S. 2012. Ceropales bipunctata [online]. Available from bugguide.net/node/view/704357, bugguide.net/node/view/702208, and bugguide.net/ node/view/701885 [accessed 6 January 2017].

Tingley, S. 2013. Ceropales bipunctata [online]. Available from bugguide.net/node/view/826211 [accessed 6 January 2017].

Townes, H. 1957. Nearctic wasps of the subfamilies Pepsinae and Ceropalinae. Bulletin of the United States National Museum, 209: 1-286.

Wright, B. 1989. The fauna of Sable Island. Curatorial Report 68. Nova Scotia Museum, Halifax, Nova Scotia, Canada. 